\title{
Peroxisome proliferator-activated receptor $\alpha$ activation regulates lipid metabolism in the feto-placental unit from diabetic rats
}

\author{
N Martínez, E Capobianco, V White, M C Pustovrh, R Higa and A Jawerbaum \\ Laboratory of Reproduction and Metabolism, CEFYBO-CONICET-UBA, School of Medicine, University of Buenos \\ Aires, Paraguay 2155, 17th floor, C1121ABG Buenos Aires, Argentina \\ Correspondence should be addressed to A Jawerbaum; Email: a.jawerbaum@abaconet.com.ar
}

\begin{abstract}
Maternal diabetes promotes an overaccumulation of lipids in the feto-placental unit and impairs feto-placental development and growth. Here, we investigated the role played by the nuclear receptor peroxisome proliferator-activated receptor (PPAR) $\alpha$ in lipid metabolism in fetuses and placentas from control and neonatal streptozotocin-induced diabetic rats. Placentas and fetuses were studied on day 13.5 of gestation. The concentrations of PPAR $\alpha$ (by Western blot) and its endogenous agonist leukotriene $B_{4}\left(\right.$ LTB $\left._{4}\right)$ (by enzyme immunoassay) were analysed. Placental explants and fetuses were cultured with $\mathrm{LTB}_{4}$ or clofibrate, and then lipid metabolism analysed (concentrations and synthesis from ${ }^{14} \mathrm{C}$-acetate of triglycerides, phospholipids, cholesterol and cholesteryl esters; release of glycerol and free fatty acids (FFAs)). We found that maternal diabetes led to increases in placental concentrations of triglycerides and cholesteryl esters, and fetal concentrations of phospholipids. PPAR $\alpha$ agonists downregulated fetal and placental lipid concentrations in control and diabetic rats. The synthesis of lipids was reduced in the diabetic placenta but increased in fetuses from diabetic animals. PPAR $\alpha$ agonists reduced the synthesis of lipids in control placenta and in the fetuses from control and diabetic rats. Glycerol and FFA release was enhanced in the diabetic placenta


increases in placental PPAR $\alpha$ concentrations. Overall, these data support a novel role of PPAR $\alpha$ as a regulator of lipid metabolism in the fetoplacental unit, relevant in maternal diabetes where fetal and placental PPAR $\alpha, \operatorname{LTB}_{\mathbf{4}}$ and lipid concentrations are altered.
\end{abstract}

Reproduction (2008) 136 95-103

\section{Introduction}

The incidence of diabetes in women in reproductive ages, as well as the complications that arise for both the mother and the fetus as a result of this pathology, is elevated (Schwartz \& Teramo 2000). Maternal diabetesinduced alterations seem to be the result of major impairments in the components of maternal metabolic fuels, and the resulting toxicities of both hyperglycaemia and hyperlipidaemia (Eriksson et al. 2003, Jawerbaum \& Gonzalez 2006). Fetal fat accretion in maternal diabetes is the result of increased fetal lipid synthesis (Kasser et al. 1981), increased fetal substrate availability, which stimulates insulin levels and fetal growth (Jansson et al. 2006), and increased free fatty acids (FFAs) derived from maternal sources (Herrera \& Amusquivar 2000). The involvement of lipids from maternal sources in fetal fat accretion is indicated by increases in lipoprotein lipase activity in diabetic placentas (Lindegaard et al. 2006) and increases in the transplacental gradient of FFAs towards the fetus, which is proportional to maternal FFA concentrations (Knopp et al. 1986). Indeed, there is a significant correlation between maternal triglyceridaemia and fetal triglyceride content (Desoye \& Shafrir 1996). Triglycerides are hydrolysed into their constituents, re-esterified, stored and re-hydrolysed within the placenta, which can regulate the nature of lipids to be transferred to the fetus (Herrera et al. 2006). However, the mechanisms that regulate placental lipid metabolism are largely unknown, and revealing that these pathways may help to understand the aetiology of feto-placental lipid alterations induced by maternal diabetes.

Peroxisome proliferator-activated receptors (PPARs) are crucial nuclear receptors controlling transcription of a variety of genes involved in lipid metabolism and cellular differentiation (Desvergne et al. 2006). Three isoforms named PPAR $\alpha, P P A R \beta / \delta$ and PPAR $\gamma$, which exhibit different ligand specificities, functions and tissue distribution, have been identified in several tissues, including the placenta (Braissant \& Wahli 1998, Fournier et al. 2007).

Both PPAR $\gamma$ and PPAR $\beta / \delta$ have essential roles in placental development, and their inactivation induces severe trophoblast differentiation defects that lead to 
fetal mortality after midgestation (Barak et al. 1999, 2002). However, although PPAR $\alpha$ - null mice do not show placental developmental abnormalities, an increased abortion and neonatal mortality rate is observed in these mice, suggesting that PPAR $\alpha$ may be involved in mother-to-fetus nutrient exchange (Peraza et al. 2006, Yessoufou et al. 2006). PPAR $\alpha$ is mainly expressed in metabolically active tissues including the liver, heart and skeletal muscle, and is crucial in the regulation of lipid catabolism (Desvergne et al. 2006, Lefebvre et al. 2006). Also, PPAR $\alpha$ is highly expressed both in the labyrinth and junctional zones of the rat placenta, and in human villous trophoblasts (Wang et al. 2002). In rat fetuses, PPAR $\alpha$ transcripts are found from day 13 of gestation, and expressed in several tissues including the nervous system, digestive track, liver and heart (Braissant \& Wahli 1998).

Fibrates are PPAR $\alpha$ pharmacological agonists that efficiently lower triglyceridaemia in experimental models of obesity and diabetes, as well as in patients with hyperlipidaemia (Watts \& Dimmitt 1999, Desvergne et al. 2004). PPAR $\alpha$ endogenous ligands are lipophylic molecules such as long-chain polyunsaturated fatty acids and the eicosanoid leukotriene $B_{4}$ $\left(\mathrm{LTB}_{4}\right)$, which is synthesised in placenta and fetuses through the activity of lipoxygenases (Lin et al. 1999, Xu et al. 2007). Treatment of rats with pharmacological PPAR $\alpha$ activators during pregnancy causes proliferation of peroxisomes and induction of peroxisomal enzyme activities in both maternal and fetal livers (Cibelli et al. 1988, Peraza et al. 2006). Reduction in maternal hypertriglyceridaemia has been found when rats are treated with fibrates during the whole pregnancy but not when treated only at term (Soria et al. 2002, Ringseis et al. 2007). These results suggest that PPAR $\alpha$ is involved in the regulation of maternal lipid metabolism; however, direct effects of PPAR $\alpha$ activation in lipid metabolism in the fetus and the placenta have not been reported yet and may be relevant in maternal diabetes.

We have previously characterised several embryonic and placental alterations in a mild experimental rat model of diabetes induced by neonatal administration of streptozotocin (Jawerbaum \& Gonzalez 2006). In embryos and placentas from these diabetic rats, there are alterations in lipid metabolism, as well as in the protein expression of PPAR $\beta / \delta$ and PPAR $\gamma, \mathrm{PPAR}$ isoforms that have specific regulatory roles in embryonic and placental lipid metabolism (Capobianco et al. 2005, Higa et al. 2007).

The aim of the present study was to evaluate whether PPAR $\alpha$ agonists regulate lipid metabolism in the fetoplacental unit from control and diabetic rats after placentation. In addition, we analysed whether maternal diabetes alters the protein expression of PPAR $\alpha$ and the levels of $\mathrm{LTB}_{4}$, its endogenous agonist, in both fetuses and placentas.
Table 1 Glycaemia, triglyceridaemia and placental and fetal leukotriene $\mathrm{B}_{4}\left(\mathrm{LTB}_{4}\right)$ concentrations in control and diabetic rats on day 13.5 of gestation.

\begin{tabular}{lll}
\hline & Control & Diabetic \\
\hline Glycaemia $(\mathrm{mg} / \mathrm{dl})$ & $99 \pm 10$ & $229 \pm 20^{+}$ \\
Triglyceridaemia $(\mathrm{g} / \mathrm{l})$ & $1.0 \pm 0.2$ & $2.1 \pm 0.3^{*}$ \\
$\begin{array}{l}\text { Placental LTB } \\
\quad \text { (pg/mg concentrations }\end{array}$ & $3.4 \pm 0.5$ & $1.4 \pm 0.3^{*}$ \\
$\begin{array}{l}\text { Fetal LTB } \\
\quad(\mathrm{pg} / \mathrm{mg} \text { protein) }\end{array}$ & $0.6 \pm 0.1$ & $0.3 \pm 0.06^{*}$ \\
\hline
\end{tabular}

Values are means \pm S.E.M., $n=8$ rats in each experimental group.

Student's $t$-test was performed. $* P<0.05{ }^{+} P<0.01$ denotes differences between the control and diabetic groups.

\section{Results \\ Rat glycaemia, triglyceridaemia and feto-placental concentrations of $L T B_{4}$ and PPAR $\alpha$}

Elevated concentrations of both glucose and triglycerides were observed in diabetic rats on day 13.5 of gestation when compared with controls (Table 1). The concentrations of the endogenous PPAR $\alpha$ agonist $\mathrm{LTB}_{4}$ and the protein expression of PPAR $\alpha$ were analysed in placentas and fetuses from control and diabetic rats on day 13.5 of gestation. $\mathrm{LTB}_{4}$ concentrations were reduced in both the placentas and the fetuses from diabetic animals when compared with controls (Table 1). PPAR $\alpha$ protein expression was enhanced in the placenta from diabetic rats in comparison with controls, while there were no changes in PPAR $\alpha$ concentrations in the fetuses from diabetic animals when compared with controls (Fig. 1). (a)

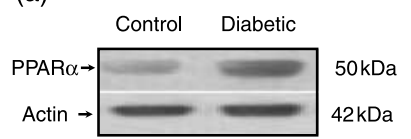

A



(b)

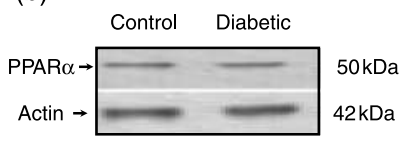

B

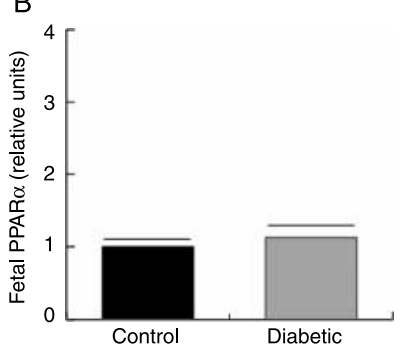

Figure 1 ( $a$ and $b$ ) Representative Western blots exhibiting PPAR $\alpha$ protein expression in (a) placentas and (b) fetuses from control and diabetic rats on day 13.5 of gestation. Antibodies employed: anti-PPAR $\alpha$ and anti-actin. (A and B) PPAR $\alpha$ concentrations relative to those of actin for each sample in (A) placentas and (B) fetuses from control and diabetic rats on day 13.5 of gestation. Values are means \pm s.E.M., $n=8$ rats in each experimental group. Student's $t$-test was performed. $* * P<0.01$ denotes differences between the control and diabetic groups. 


\section{Effect of PPAR $\alpha$ agonists on placental and fetal lipid concentrations}

Fetuses and placentas obtained from control and diabetic rats on day 13.5 of gestation were cultured for $3 \mathrm{~h}$ in the presence or absence of the PPAR $\alpha$ agonists $\mathrm{LTB}_{4}(0.1 \mu \mathrm{M})$ or clofibrate $(20 \mu \mathrm{M})$, and placental and fetal lipid concentrations were analysed. We found an increase in triglycerides and cholesteryl esters, but no differences in the levels of phospholipids and cholesterol in the placenta from diabetic animals when compared with controls without additions (Fig. 2).

When the effect of PPAR $\alpha$ agonists was analysed in the placenta from control and diabetic rats, we found that the pharmacological agonist clofibrate led to a reduction in all lipid species analysed in diabetic tissues and to a reduction in the levels of triglycerides, phospholipids and cholesteryl esters in control tissues (Fig. 2). On the other hand, although the endogenous agonist $\mathrm{LTB}_{4}$ did not significantly change any lipid species analysed in the placenta from control rats, in the placenta from diabetic rats $\mathrm{LTB}_{4}$ specifically reduced the concentrations of phospholipids and cholesterol, those lipid species that were not overaccumulated in these tissues (Fig. 2).

When lipid mass was analysed in the fetuses (Fig. 3), we found that phospholipids were the lipid species overaccumulated in the fetuses from diabetic animals, whereas no changes in the concentrations of triglycerides, cholesteryl esters and cholesterol were found when fetuses from diabetic rats were compared with controls. When the effects of PPAR $\alpha$ agonists were analysed in the fetuses from control and diabetic rats, we found that both clofibrate and $\mathrm{LTB}_{4}$ had similar effects, and were able to reduce the concentrations of triglycerides, cholesteryl esters and cholesterol in the fetuses from both the control and diabetic animals. In contrast, neither clofibrate nor $\mathrm{LTB}_{4}$ was able to modify the concentrations of phospholipids, the only lipid species that was overaccumulated in the fetuses from diabetic animals (Fig. 3).

\section{Effects of PPAR $\alpha$ agonists on placental and fetal lipid syntheses}

The de novo lipid synthesis was analysed in fetuses and placentas from control and diabetic rats on day 13.5 of gestation that were cultured in the presence of ${ }^{14} \mathrm{C}$ acetate as a tracer either with or without the addition of $\mathrm{LTB}_{4}(0.1 \mu \mathrm{M})$ or clofibrate $(20 \mu \mathrm{M})$. When the effect of PPAR $\alpha$ agonists on the de novo lipid synthesis was analysed in the placenta from control rats (Fig. 4), a reduction in the synthesis of triglycerides, cholesteryl esters and cholesterol was found in the presence of $\mathrm{LTB}_{4}$, while the synthesis of all lipid species analysed was decreased in the presence of clofibrate. In contrast, there were no effects of either $\mathrm{LTB}_{4}$ or clofibrate on the synthesis of the lipids analysed in the placenta from diabetic rats,
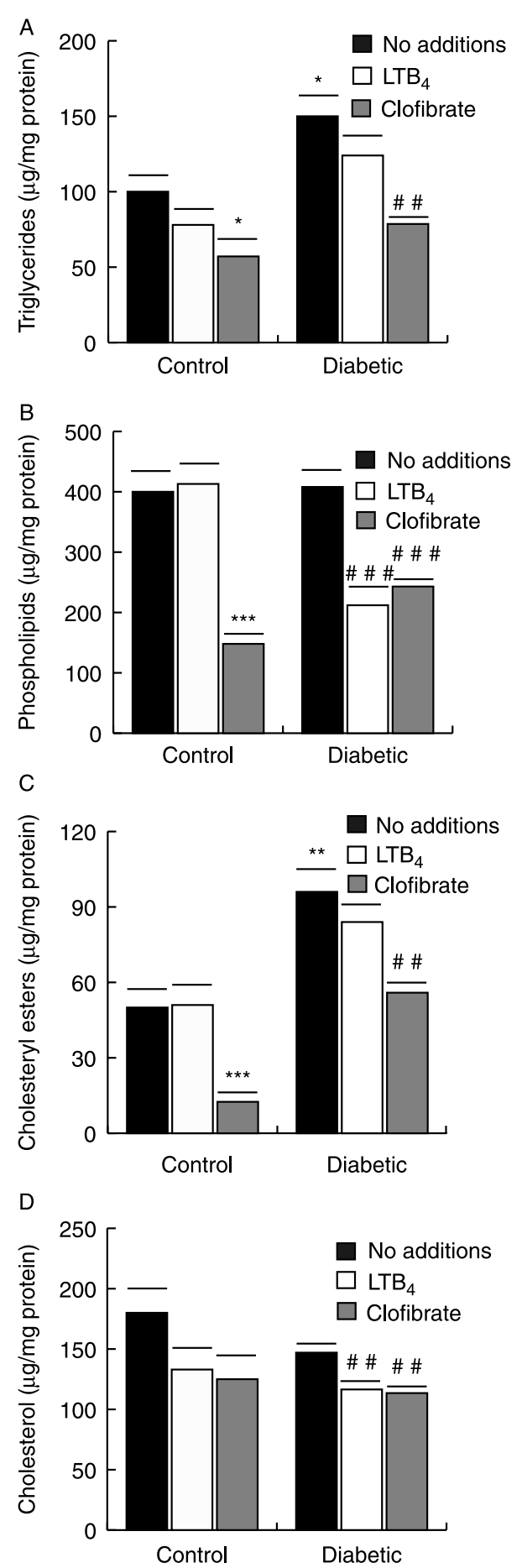

Figure 2 Effect of $\mathrm{LTB}_{4}$ and clofibrate additions on the concentrations of (A) triglycerides, (B) phospholipids, (C) cholesteryl esters and (D) cholesterol in placentas obtained from control and diabetic rats on day 13.5 of gestation. Placentas were incubated either with or without the addition of $0.1 \mu \mathrm{MLTB}_{4}$ and $20 \mu \mathrm{M}$ clofibrate for $3 \mathrm{~h}$ in KRB followed by lipids evaluation. Values are means \pm s.E.M.; $n=9$ rats per group. ANOVA followed by Tukey's test was performed. ${ }^{*} P<0.05$ and *** $P<0.001$ denote differences from control group without additions; ${ }^{\# \#} P<0.01$ and ${ }^{\# \# \#} P<0.001$ denote differences from diabetic group without additions. 

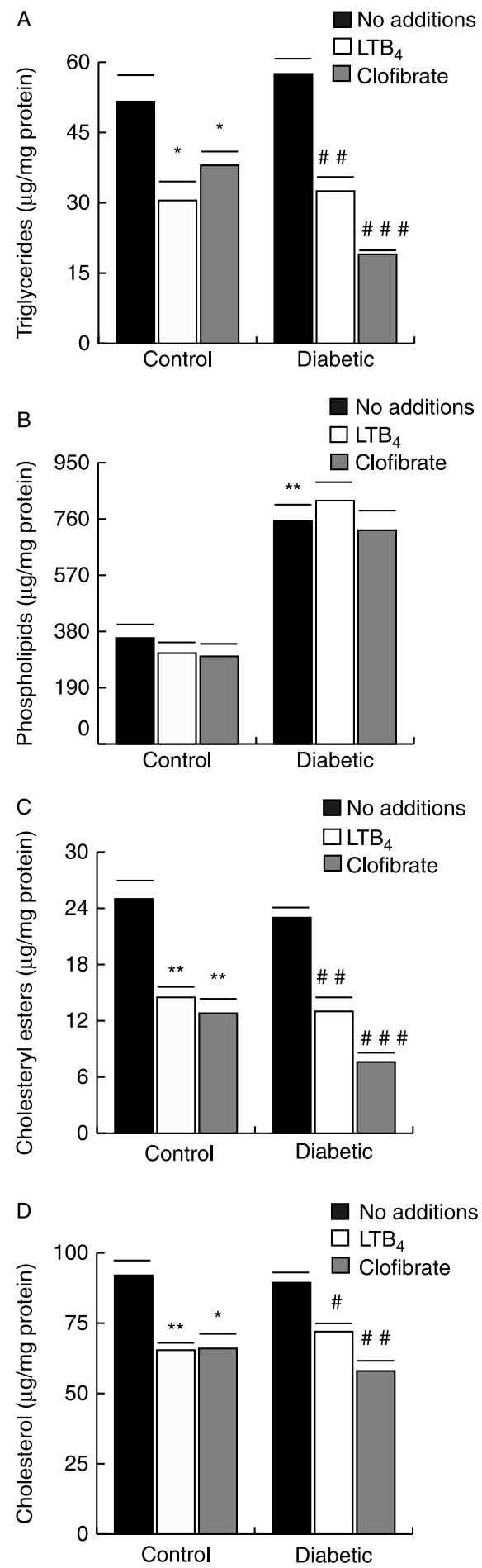

Figure 3 Effect of $\mathrm{LTB}_{4}$ and clofibrate additions on the concentrations of (A) triglycerides, (B) phospholipids, (C) cholesteryl esters and (D) cholesterol in fetuses obtained from control and diabetic rats on day 13.5 of gestation. Fetuses were incubated either with or without the addition of $0.1 \mu \mathrm{M} \mathrm{LTB}_{4}$ and $20 \mu \mathrm{M}$ clofibrate for $3 \mathrm{~h}$ in KRB followed by lipids evaluation. Values are means \pm S.E.M.; $n=8$ rats per group. ANOVA followed by Tukey's test was performed. ${ }^{*} P<0.05$ and ${ }^{*} * P<0.01$ denote differences from control group without additions; ${ }^{\#} P<0.05,{ }^{\#} P<0.01$ and ${ }^{\# \#} P<0.001$ denote from diabetic group without additions.
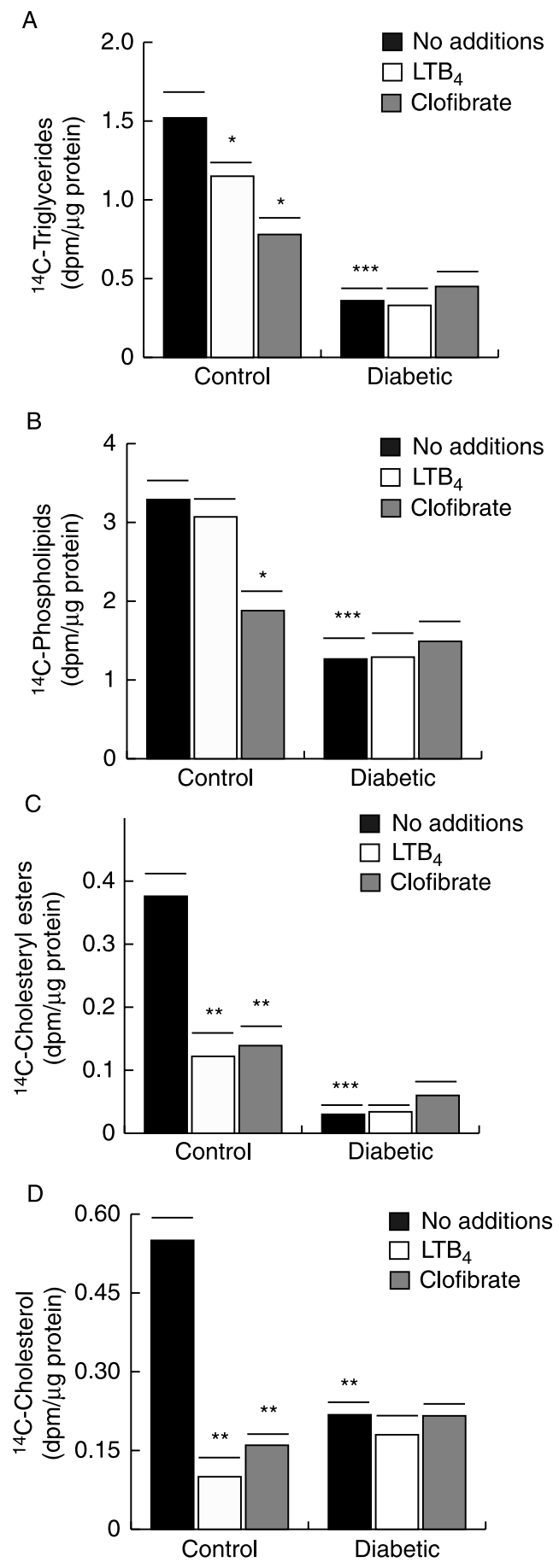

Figure 4 Effect of $\mathrm{LTB}_{4}$ and clofibrate additions on the de novo synthesis of (A) triglycerides, (B) phospholipids, (C) cholesteryl esters and (D) cholesterol in placentas obtained from control and diabetic rats on day 13.5 of gestation. Placentas were incubated either with or without the addition of $0.1 \mu \mathrm{M} \mathrm{LTB}_{4}$ and $20 \mu \mathrm{M}$ clofibrate for $3 \mathrm{~h}$ in KRB in the presence of $1 \mu \mathrm{M}{ }^{14} \mathrm{C}$-acetate $(53 \mathrm{mCi} / \mathrm{mmol})$ followed by evaluation of the incorporation of the tracer to lipids. Values are means \pm S.E.M.; $n=8$ rats per group. ANOVA followed by Tukey's test was performed. ${ }^{*} P<0.05$, ${ }^{* *} P<0.01$ and ${ }^{* * *} P<0.001$ denote differences from control groups without additions. 
which showed reduced de novo synthesis of all lipid species studied when compared with controls (Fig. 4).

On the other hand, in the fetuses from control animals (Fig. 5), LTB $_{4}$ did not significantly change the synthesis of any lipid species, while clofibrate reduced the synthesis of triglycerides and cholesteryl esters. In contrast, both $\mathrm{LTB}_{4}$ and clofibrate were able to reduce the synthesis of all lipid species analysed in the fetuses from diabetic animals, which showed a high synthesis rate of these lipid species (Fig. 5).

\section{Effects of PPAR $\alpha$ agonists on placental release of glycerol and FFAs}

To further address direct lipolytic effects of PPAR $\alpha$ agonists, glycerol and FFAs were analysed in the media where placentas and fetuses from control and diabetic rats on day 13.5 of gestation were cultured for $3 \mathrm{~h}$ in the presence or absence of the PPAR $\alpha$ agonists studied. Glycerol and FFAs were below the limit of detection of the employed techniques in the culture media of the fetuses. When the effects of PPAR $\alpha$ agonists on glycerol and FFA release were analysed in the placenta from control rats, we found an increase in glycerol and FFA concentrations in the presence of $\mathrm{LTB}_{4}$ and clofibrate, when compared with the controls without additions (Fig. 6). In contrast, PPAR $\alpha$ agonists were devoid of effect in the placenta from diabetic animals, in which both glycerol and FFA concentrations were increased when compared with controls (Fig. 6).

\section{Discussion}

The present work describes a novel role of PPAR $\alpha$ as a regulator of lipid metabolism in the fetuses and placentas from healthy and diabetic rats. PPAR $\alpha$ agonists lead to a reduction in the concentrations of several lipid species in the fetuses and the placenta as a result of their effects on both lipid catabolism and lipid synthesis. The observed effects of PPAR $\alpha$ agonists may contribute to the understanding of the impairments in lipid metabolism in fetuses and placentas from diabetic rats, which showed alterations in the concentrations of PPAR $\alpha$ and its endogenous agonist $\mathrm{LTB}_{4}$.

We found that $\mathrm{LTB}_{4}$ production was reduced in the placenta and the fetuses from diabetic animals, an alteration that may impair feto-placental development and growth. Consistent with this hypothesis, murine pregnancies predisposed to spontaneous abortion have reduced $\mathrm{LTB}_{4}$ levels in the feto-placental unit (Gendron et al. 1992). Interestingly, increased abortion and neonatal mortality rates have also been observed in control and diabetic Ppara- null mice, in which an altered balance in Th1/Th2 cytokine response is observed (Yessoufou et al. 2006). On the other hand, mice that overexpress PPAR $\alpha$ show defects in cardiac development and metabolism (Finck et al. 2002), and fetuses from rats
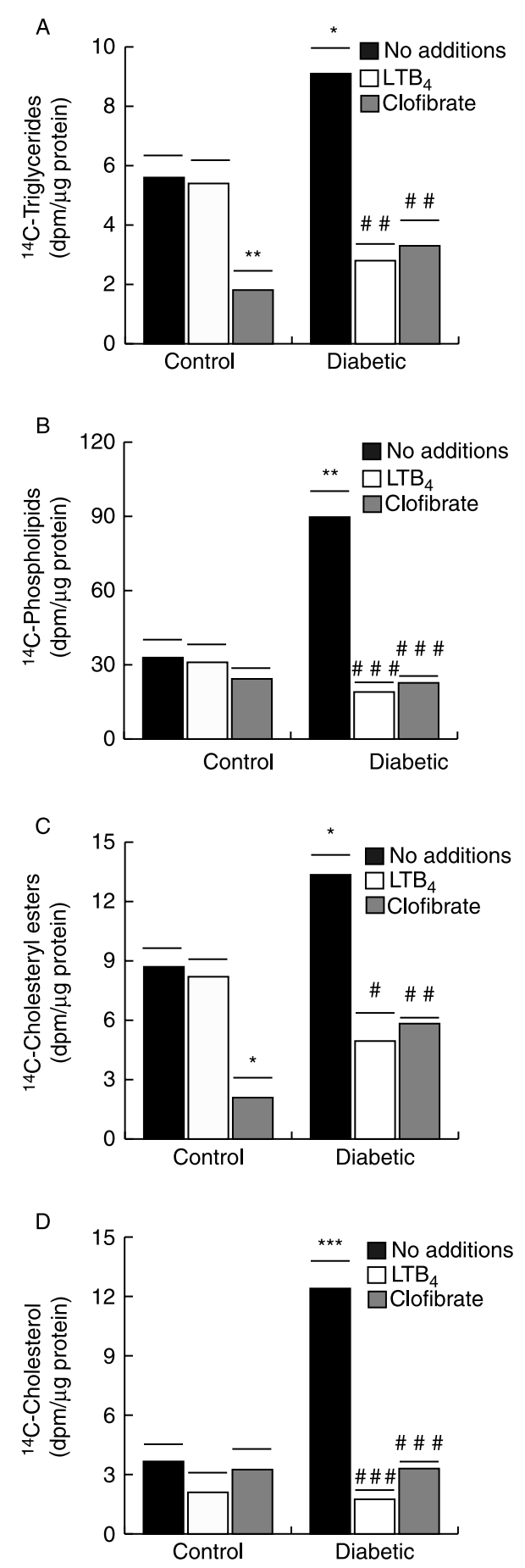

Figure 5 Effect of $\mathrm{LTB}_{4}$ and clofibrate additions on the de novo synthesis of (A) triglycerides, (B) phospholipids, (C) cholesteryl esters and (D) cholesterol in fetuses obtained from control and diabetic rats on day 13.5 of gestation. Fetuses were incubated either with or without the addition of $0.1 \mu \mathrm{M} \mathrm{LTB}_{4}$ and $20 \mu \mathrm{M}$ clofibrate for $3 \mathrm{~h}$ in KRB in the presence of $1 \mu \mathrm{M}{ }^{14} \mathrm{C}$-acetate $(53 \mathrm{mCi} / \mathrm{mmol})$ followed by evaluation of the incorporation of the tracer to lipids. Values are means \pm s.E.M.; $n=8$ rats per group. ANOVA followed by Tukey's test was performed. $* P<0.05, * * P<0.01$ and ${ }^{* * *} P<0.001$ denote differences from control groups without additions; ${ }^{\sharp} P<0.05,{ }^{\# \#} P<0.01$ and ${ }^{\# \# \#} P<0.001$ denote differences from diabetic group without additions. 

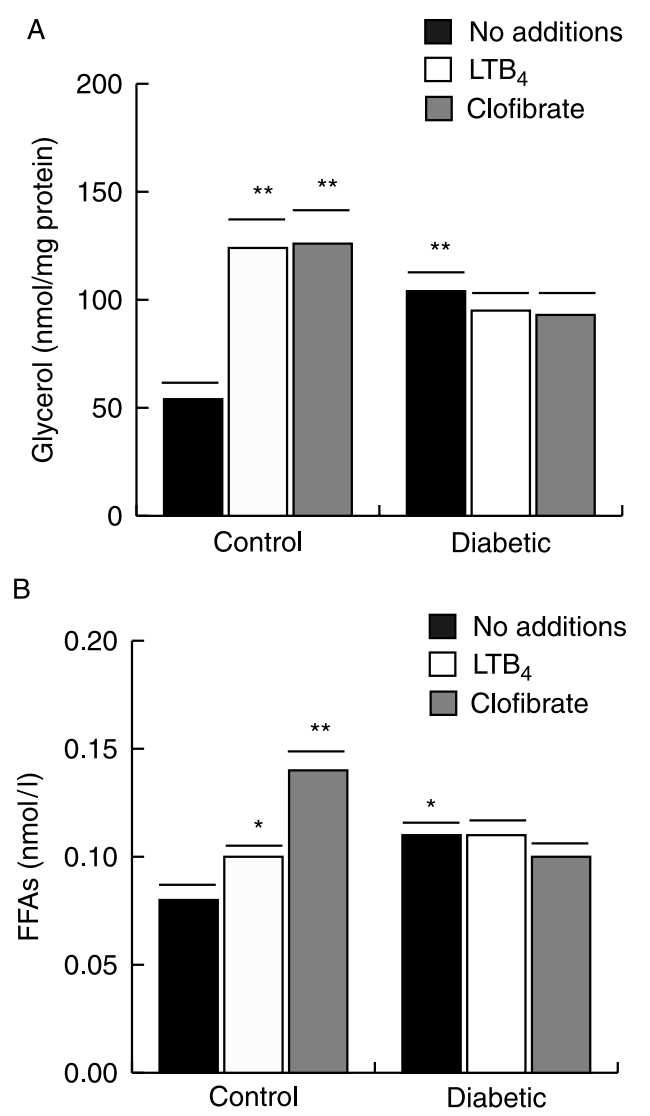

Figure 6 Effect of $\mathrm{LTB}_{4}$ and clofibrate additions on (A) glycerol and (B) FFA release in placentas obtained from control and diabetic rats on day 13.5 of gestation. Placentas were incubated either with or without the addition of $0.1 \mu \mathrm{M} \mathrm{LTB}$ and $20 \mu \mathrm{M}$ clofibrate for $3 \mathrm{~h}$ in KRB followed by evaluation of glycerol and FFAs in the culture media. Values are means \pm s.E.M.; $n=8$ rats per group. ANOVA followed by Tukey's test was performed. ${ }^{*} P<0.05$ and ${ }^{* *} P<0.01$ denote differences from control groups without additions.

treated with fibrates do not show malformations but present metabolic alterations (Soria et al. 2002, Peraza et al. 2006), suggesting that proper concentrations of PPAR $\alpha$ and their ligands are needed for a proper development and growth. In this work, we found that PPAR $\alpha$ concentrations were similar in fetuses from control and diabetic rats, but were increased in the placenta from diabetic animals, an alteration that may be related to a disregulated lipid utilisation in the fetoplacental unit.

Alterations in the feto-placental lipid metabolism associated with maternal diabetes depend on the type and severity of the diabetic condition, and also on the developmental stage (Desoye \& Shafrir 1996, Grissa et al. 2007). We have previously shown that during early organogenesis lipid synthesis is decreased in embryos from mild and severe diabetic rats whereas triglycerides are overaccumulated in embryos obtained from severe diabetic rats (Jawerbaum et al. 2002, Sinner et al. 2003). However, in this work, we identified phospholipids as the lipid species overaccumulated in the fetuses from mild diabetic rats on day 13.5 of gestation, together with an increase in the de novo lipid synthesis that is likely to contribute to the increased fetal lipid mass. These differences probably reflect developmental changes occurring after mid-pregnancy in the rat, when the efficient mother-to-fetus nutrient exchange through the chorioallantoic placenta is initiated (Ain et al. 2003).

On the other hand, overaccumulation of triglycerides and cholesteryl esters was found in the diabetic placenta, despite the compensatory reduction in the de novo lipid synthesis observed. Our previous studies performed in term placenta in the same diabetic model have shown reductions in the de novo lipid synthesis but no changes in lipid mass, supporting the concept that the capacity of accretion of lipids in the placenta depends on the developmental stage, and is reduced at term (Capobianco et al. 2005).

There is little evidence of PPAR-mediated regulation of lipid metabolism in the placenta (Xu et al. 2007). PPAR $\gamma$ has been found to regulate uptake of FFAs, formation of lipid droplets and the de novo lipid synthesis in rat trophoblasts and placental tissues (Capobianco et al. 2005, Schaiff et al. 2007).

In this work, we focused on PPAR $\alpha$, a major regulator of lipid metabolism that regulates the transcription of multiple genes involved in the catabolism and the synthesis of lipids mainly in the liver and also in other tissues (Lefebvre et al. 2006). The degree of induction of these genes is specific for each tissue and depends on the levels of PPAR $\alpha$ and its different ligands and co-activators (Desvergne et al. 2006). Some differences were observed in this work between the effects of PPAR $\alpha$ agonists clofibrate and $\mathrm{LTB}_{4}$ on the regulation of fetoplacental lipid metabolism, which suggests that clofibrate effects are more potent, while those of $\mathrm{LTB}_{4}$ are more specific. Indeed, although both PPAR $\alpha$ agonists were able to reduce lipid concentrations in the placenta and the fetuses from control and diabetic rats, $\mathrm{LTB}_{4}$ was able to reduce only those lipid species that are not overproduced in both the placenta and fetuses from diabetic animals. We speculate that overaccumulation of lipids might be specific for triglycerides and cholesteryl esters in the diabetic placenta and for phospholipids in the fetuses from diabetic rats due to the lack of $\mathrm{LTB}_{4}$ catabolic effects on them.

On the other hand, the observed capacity of PPAR $\alpha$ agonists to reduce the de novo lipid synthesis in control placentas was not observed in the diabetic placenta probably due to the reduced synthesis of all lipid species found in these diabetic tissues. Whether or not the upregulation of PPAR $\alpha$ concentrations observed in the diabetic placenta is involved in the reduced lipid synthesis found in these tissues remains to be established.

The de novo lipid synthesis in the fetuses from diabetic animals was highly elevated, an alteration that probably contributes to their increased lipid accumulation (Kasser 
et al. 1981), and that was reduced through the activation of PPAR $\alpha$. Similar effects of PPAR $\alpha$ agonists on the de novo lipid synthesis were observed in the fetuses from control and diabetic animals, consistent with a similar PPAR $\alpha$ protein expression. Nevertheless, the degree of activation of PPAR $\alpha$ by its agonists will require further research as they may have PPAR $\alpha$-independent effects (Cui et al. 2001, Miyahara et al. 2006).

Most enzymes required for FFA oxidation are highly expressed in the placenta, an organ capable of both transporting fatty acids to the fetus and using them as metabolic fuels (Shekhawat et al. 2003). The capacity of releasing glycerol as an index of lipid catabolism in placental explants has previously been reported (Ramsay et al. 1991). In this work, we found that both pharmacological and endogenous PPAR $\alpha$ agonists stimulated glycerol and FFA release in the control placenta. In addition, both glycerol and FFA release was elevated in the diabetic placenta, a catabolic pathway that seems to occur despite the low concentrations of $\mathrm{LTB}_{4}$ and probably as a result of the increased PPAR $\alpha$ concentrations. By contrast, PPAR $\alpha$ agonists did not change glycerol and FFA release in the diabetic placenta, probably due to a further oxidation of FFAs and glycerol as it occurs in different tissues as a result of the stimulation of the increased PPAR $\alpha$ concentrations (Patsouris et al. 2004, Desvergne et al. 2006).

In conclusion, here we demonstrate an important role of PPAR $\alpha$ in fetal and placental lipid metabolism, as PPAR $\alpha$ agonists reduce lipid concentrations through the regulation of both a reduction in the de novo lipid synthesis and an increase in lipid catabolism in these intrauterine tissues. These PPAR $\alpha$ signalling pathways are disregulated and appear to be especially relevant in maternal diabetes, where several alterations in feto-placental lipid metabolism are found, probably as a response to the excess lipids derived from maternal circulation.

\section{Materials and Methods}

\section{Animals}

Albino Wistar rats were bred in the laboratory with free access to Purina rat chow and water, under a $14 \mathrm{~h}$ light: $10 \mathrm{~h}$ darkness cycle. At 2 days of age, they were injected either with streptozotocin (90 mg/kg s.c.; Sigma-Aldrich) in citrate buffer $(0.05 \mathrm{M}, \mathrm{pH} 4.5)$ or with buffer alone (controls). The spontaneous evolution of this treatment leads to a diabetic state (Portha et al. 1979), characterised by glycaemia values between 180 and $230 \mathrm{mg} / \mathrm{dl}$ and marked glucose intolerance, while control rat glycaemia levels were below $100 \mathrm{mg} / \mathrm{dl}$. This experimental model is compatible with the pregnant state, and the reproductive characteristics of this model have previously been reported (Jawerbaum \& Gonzalez 2005). In the evening of proestrus, control and diabetic females weighing between 200 and $300 \mathrm{~g}$ were caged overnight with control males. The following day was designated as day 0.5 of pregnancy if sperm cells were found in the vaginal smear. The guidelines for the care and use of animals approved by the local institution were followed, according to 'Principles of laboratory animal care' (NIH publication no. 85-23, revised 1985; http://grants1.nih. gov/grants/olaw/references/phspol.htm).

\section{Tissue preparations}

Animals were killed by cervical dislocation on day 13.5 of gestation, after the initiation of mother-to-fetus circulation through the placenta (Ain et al. 2003) and when PPAR $\alpha$ is expressed in both placental and fetal tissues (Braissant \& Wahli 1998). Placentas and fetuses were removed and placed in Petri dishes containing Krebs-Ringer bicarbonate solution (KRB, ionic composition: $5.5 \mathrm{mM}$ glucose, $145 \mathrm{mM} \mathrm{Na}^{+}, 2.2 \mathrm{mM}$ $\mathrm{Ca}^{++}, 1.2 \mathrm{mM} \mathrm{Mg}^{++}, 127 \mathrm{mM} \mathrm{Cl}^{-}, 25 \mathrm{mM} \mathrm{HCO}_{3}^{-}, 1.2 \mathrm{mM}$ $\mathrm{SO}_{4}^{2-}$ and $1.2 \mathrm{mM}^{2} \mathrm{PO}_{4}^{3-}$ ). Placentas and fetuses were either frozen at $-70{ }^{\circ} \mathrm{C}$ for further analyses of $\mathrm{LTB}_{4}$ and PPAR $\alpha$ concentrations or prepared for the evaluation of the effect of PPAR $\alpha$ agonists on lipid concentrations, the de novo lipid synthesis and lipid catabolism, as follows. Two fetuses or one placenta selected at random from each animal $(n=8$ or 9 animals in each experimental group) were incubated for $3 \mathrm{~h}$ as previously done to evaluate regulation of lipid metabolism (White et al. 2004, Capobianco et al. 2005) in a metabolic shaker under an atmosphere of $5 \% \mathrm{CO}_{2}$ and $95 \% \mathrm{O}_{2}$ at $37{ }^{\circ} \mathrm{C}$, with or without the addition of either $\mathrm{LTB}_{4}(0.1 \mu \mathrm{M}$; Cayman Chemical Co., Ann Arbor, MI, USA) or clofibrate $(20 \mu \mathrm{M}$; Sigma-Aldrich). Thereafter, tissues were frozen at $-70{ }^{\circ} \mathrm{C}$ for further analysis of lipid concentrations, and aliquots of incubation medium were frozen at $-20{ }^{\circ} \mathrm{C}$ for further determination of glycerol and FFA concentrations.

To analyse the de novo lipid synthesis, fetuses and placentas were incubated as described above, with the addition of $1 \mu \mathrm{Ci}$ ${ }^{14} \mathrm{C}$-acetate (53 mCi/mmol; Amersham Biosciences), and then stored at $-70{ }^{\circ} \mathrm{C}$ until determination of the newly formed radioactive lipids, as described below.

\section{$L^{T} B_{4}$ concentrations analysis}

$\mathrm{LTB}_{4}$ concentrations were measured in control and diabetic fetuses and placentas by employing a commercial enzyme immunoassay kit (Cayman Chemical Co). One fetus or one placenta from each rat ( $n=8$ rats in each experimental group) was selected at random. Eicosanoids were extracted twice in absolute ethanol. The extracts were dried in a Savant SpeedVac concentrator (Savant, Hicksville, NY, USA) and reconstituted with $200 \mu \mathrm{l}$ assay buffer provided by the commercial kit. Briefly, the kit uses a polyclonal antibody against $\mathrm{LTB}_{4}$ that binds in a competitive manner the eicosanoid in the sample or an acetylcholinesterase molecule, which has $\mathrm{LTB}_{4}$ covalently attached to it. After a simultaneous incubation, a $p$-nitrophenyl phosphate substrate was added, and the yellow colour generated was evaluated on a microplate reader at $405 \mathrm{~nm}$.

\section{PPAR $\alpha$ protein expression assessment}

Two fetuses or one placenta from each rat $(n=8$ rats in each experimental group) were selected at random for the determination of PPAR $\alpha$ protein expression by Western blot, 
as previously performed for other PPAR isoforms (Jawerbaum et al. 2004, Higa et al. 2007). The tissues were homogenised in $300 \mu$ ice-cold lysis buffer $(\mathrm{pH} 7.4,20 \mathrm{mM}$ Tris-HCl, $150 \mathrm{mM}$ $\mathrm{NaCl}, 1 \%$ Triton $\mathrm{X}-100)$ containing $1 \%$ protease inhibitor cocktail and then incubated on ice for $2 \mathrm{~h}$. Tissues were centrifuged at $7200 \mathrm{~g}$ for $10 \mathrm{~min}$ at $4{ }^{\circ} \mathrm{C}$ and the supernatant removed. Protein concentrations were determined by Bradford method using a protein assay reagent (Bio-Rad, Inc). Equal amounts of protein samples were separated with the use of $15 \%$ SDS-PAGE. Proteins were then transferred into nitrocellulose membranes, which were blocked overnight with $1 \%$ BSA and then incubated with a polyclonal rabbit $\lg \mathrm{G}$ antibody either against PPAR $\alpha$ (1:200; Santa Cruz Biotechnology, Santa Cruz, CA, USA) or actin (Sigma-Aldrich) at $4{ }^{\circ} \mathrm{C}$ overnight. After washing with Tris buffer saline and Tween $0.05 \%$, the blots were treated with horseradish peroxidase-conjugated secondary antibody for $1 \mathrm{~h}$ and washed several times. The specific signals were visualised using the enhanced chemiluminescence system (Amersham Biosciences). The identity of PPAR $\alpha$ was established by the use of molecular weight standards, which allow the identification of the band revealed at the expected size of $50 \mathrm{kDa}$, which was absent in the negative control experiments performed in the absence of primary antibody. Actin reactivity was detected with a phosphatase alkaline-conjugated secondary antibody. The relative intensity of protein signals was quantified by densitometry using the Sigma Gel Program (Sigma-Aldrich).

\section{Lipid concentrations assessment}

Lipid concentrations were determined by thin layer chromatography (TLC), as previously described (Capobianco et al. 2005). Briefly, placental and fetal lipids were extracted in methanolchloroform in the ratio of $2: 1(\mathrm{v} / \mathrm{v})$ and then concentrated in a Savant Speed-Vac concentrator. Total lipids were chromatographed with a solvent system consisting of hexane:ethyl ether:acetic acid in the ratio of 80:20:2 (v/v). After development, the TLC plate was dried for 5 min under an $\mathrm{N}_{2}$ stream and the lipids were stained with iodine vapours. Lipid species levels were quantified by comparison with known amounts of pure lipid standards run on the same plate. The plates were scanned and analysed by densitometry using the Sigma Gel Program (Sigma-Aldrich).

\section{Determination of de novo lipid synthesis}

Fetal and placental lipid syntheses from ${ }^{14} \mathrm{C}$-acetate were evaluated as previously (Higa et al. 2007). Briefly, following the incubations performed in the presence of ${ }^{14} \mathrm{C}$-acetate $(53 \mathrm{mCi} /$ mmol) either with or without the addition of $\operatorname{LTB}_{4}(0.1 \mu \mathrm{M})$ or clofibrate $(20 \mu \mathrm{M})$, lipids were separated by TLC as described above. Thereafter, the radioactive spots corresponding to the different ${ }^{14} \mathrm{C}$-labelled lipid species were scrapped into vials and counted in a liquid scintillation counter.

\section{Determination of FFA and glycerol release}

FFAs and glycerol generated during the hydrolysis of triglycerides and phospholipids and released to the culture media of the placental tissues were determined. FFAs were determined by employing a colorimetric commercial kit (Randox Laboratories, Antrim, UK). Glycerol was determined by an enzymatic method as described previously (Young et al. 1988, White et al. 2006). Briefly, $0.2 \mathrm{ml}$ placental explant incubation medium was allowed to react with $1 \mathrm{ml}$ assay solution containing glycine $(15 \mathrm{mg} / \mathrm{ml}), \mathrm{MgCl}_{2}(0.4 \mathrm{mg} / \mathrm{ml})$, ATP $(0.75 \mathrm{mg} / \mathrm{ml}), \mathrm{NAD}^{+}(0.36 \mathrm{mg} / \mathrm{ml})$, hydrazine hydrate $(0.2 \mathrm{ml} /$ $\mathrm{ml})$, glycerokinase $(0.42$ units $/ \mathrm{ml})$ and glycerol-3-phosphate dehydrogenase (2.5 units/ml; Roche Diagnostics Corporation). After 45 min, optical density was read at $340 \mathrm{~nm}$ in a microtitre plate using calibration curves of glycerol standards.

\section{Statistical analysis}

Results are expressed as means \pm s.E.M. Comparisons between groups were performed employing either one-way ANOVA in conjunction with Tukey's test or Student's $t$-test, where appropriate. The statistical level of significance was defined as $P<0.05$.

\section{Acknowledgements}

In memoriam to Elida González (1953-2007), who greatly contributed as a mentor of this work, and who passed away last July. This work was supported by grants from Agencia de Promoción Científica y Tecnológica de Argentina (PICT 05-10652 and PICT 06-00084) and from Consejo Nacional de Investigaciones Científicas y Técnicas (PIP 5397/05 and PIP 5317/05). The authors declare that there is no conflict of interest that would prejudice the impartiality of this scientific work.

\section{References}

Ain R, Canham LN \& Soares MJ 2003 Gestation stage-dependent intrauterine trophoblast cell invasion in the rat and mouse: novel endocrine phenotype and regulation. Developmental Biology $\mathbf{2 6 0}$ 176-190.

Barak Y, Nelson MC, Ong ES, Jones YZ, Ruiz-Lozano P, Chien KR, Koder A \& Evans RM 1999 PPAR gamma is required for placental, cardiac, and adipose tissue development. Molecular Cell 4 585-595.

Barak Y, Liao D, He W, Ong ES, Nelson MC, Olefsky JM, Boland R \& Evans RM 2002 Effects of peroxisome proliferator-activated receptor delta on placentation, adiposity, and colorectal cancer. PNAS 99 303-308.

Braissant O \& Wahli W 1998 Differential expression of peroxisome proliferator-activated receptor-alpha, -beta, and -gamma during rat embryonic development. Endocrinology 139 2748-2754.

Capobianco E, Jawerbaum A, Romanini MC, White V, Pustovrh C, Higa R, Martinez N, Mugnaini MT, Sonez C \& Gonzalez E 2005 15 -Deoxy-Delta $(12,14)$-prostaglandin $\mathrm{J} 2$ and peroxisome proliferatoractivated receptor gamma (PPAR $\gamma$ ) levels in term placental tissues from control and diabetic rats: modulatory effects of a PPAR $\gamma$ agonist on nitridergic and lipid placental metabolism. Reproduction, Fertility, and Development 17 423-433.

Cibelli A, Stefanini S \& Ceru MP 1988 Peroxisomal beta-oxidation and catalase activities in fetal rat liver: effect of maternal treatment with clofibrate. Cellular and Molecular Biology 34 191-205.

Cui X, Kawashima H, Barclay TB, Peters JM, Gonzalez FJ, Morgan ET \& Strobel HW 2001 Molecular cloning and regulation of expression of two novel mouse CYP4F genes: expression in peroxisome proliferatoractivated receptor alpha-deficient mice upon lipopolysaccharide and clofibrate challenges. Journal of Pharmacology and Experimental Therapeutics 296 542-550. 
Desoye G \& Shafrir E 1996 The human placenta in diabetic pregnancy. Diabetes Reviews 4 70-89.

Desvergne B, Michalik L \& Wahli W 2004 Be fit or be sick: peroxisome proliferator-activated receptors are down the road. Molecular Endocrinology 18 1321-1332.

Desvergne B, Michalik L \& Wahli W 2006 Transcriptional regulation of metabolism. Physiological Reviews 86 465-514.

Eriksson UJ, Cederberg J \& Wentzel P 2003 Congenital malformations in offspring of diabetic mothers-animal and human studies. Reviews in Endocrine and Metabolic Disorders 4 79-93.

Finck BN, Lehman JJ, Leone TC, Welch MJ, Bennett MJ, Kovacs A, Han X, Gross RW, Kozak R, Lopaschuk GD et al. 2002 The cardiac phenotype induced by PPARalpha overexpression mimics that caused by diabetes mellitus. Journal of Clinical Investigation 109 121-130.

Fournier T, Tsatsaris V, Handschuh K \& Evain-Brion D 2007 PPARs and the placenta. Placenta 28 65-76.

Gendron RL, Farookhi R \& Baines MG 1992 Murine pregnancies predisposed to spontaneous resorption show alterations in the concentrations of leukotriene B4 and prostaglandin E2. Biology of Reproduction $4772-75$.

Grissa O, Ategbo JM, Yessoufou A, Tabka Z, Miled A, Jerbi M, Dramane KL, Moutairou K, Prost J, Hichami A et al. 2007 Antioxidant status and circulating lipids are altered in human gestational diabetes and macrosomia. Translational Research 150 164-171.

Herrera E \& Amusquivar E 2000 Lipid metabolism in the fetus and the newborn. Diabetes/Metabolism Research and Reviews 16 202-210.

Herrera E, Amusquivar E, Lopez-Soldado I \& Ortega H 2006 Maternal lipid metabolism and placental lipid transfer. Hormone Research 65 (Suppl 3) 59-64.

Higa R, Gonzalez E, Pustovrh MC, White V, Capobianco E, Martinez N \& Jawerbaum A 2007 PPAR $\delta$ and its activator PGI2 are reduced in diabetic embryopathy: involvement of PPAR $\delta$ activation in lipid metabolic and signalling pathways in rat embryo early organogenesis. Molecular Human Reproduction 13 103-110.

Jansson T, Cetin I, Powell TL, Desoye G, Radaelli T, Ericsson A \& Sibley CP 2006 Placental transport and metabolism in fetal overgrowth - a workshop report. Placenta 27 (Supplement A) S109-S113.

Jawerbaum A \& Gonzalez E 2005 The role of alterations in arachidonic acid metabolism and nitric oxide homeostasis in rat models of diabetes during early pregnancy. Current Pharmaceutical Design 11 1327-1342.

Jawerbaum A \& Gonzalez E 2006 Diabetic pregnancies: the challenge of developing in a pro-inflammatory environment. Current Medicinal Chemistry 13 2127-2138.

Jawerbaum A, Sinner D, White V, Pustovrh C, Capobianco E \& Gonzalez E 2002 Modulation of nitric oxide concentration and lipid metabolism by 15-deoxy Delta12,14prostaglandin J2 in embryos from control and diabetic rats during early organogenesis. Reproduction 124 625-631.

Jawerbaum A, Capobianco E, Pustovrh C, White V, Baier M, Salzberg S, Pesaresi M \& Gonzalez E 2004 Influence of peroxisome proliferatoractivated receptor gamma activation by its endogenous ligand 15-deoxy Delta12,14 prostaglandin J2 on nitric oxide production in term placental tissues from diabetic women. Molecular Human Reproduction 10 671-676.

Kasser TR, Martin RJ \& Allen CE 1981 Effect of gestational alloxan diabetes and fasting on fetal lipogenesis and lipid deposition in pigs. Biology of the Neonate 40 105-112.

Knopp RH, Warth MR, Charles D, Childs M, Li JR, Mabuchi H \& Van Allen MI 1986 Lipoprotein metabolism in pregnancy, fat transport to the fetus, and the effects of diabetes. Biology of the Neonate $\mathbf{5 0}$ 297-317.

Lefebvre P, Chinetti G, Fruchart JC \& Staels B 2006 Sorting out the roles of PPAR alpha in energy metabolism and vascular homeostasis. Journal of Clinical Investigation 116 571-580.

Lin Q, Ruuska SE, Shaw NS, Dong D \& Noy N 1999 Ligand selectivity of the peroxisome proliferator-activated receptor alpha. Biochemistry $\mathbf{3 8}$ $185-190$.

Lindegaard ML, Damm P, Mathiesen ER \& Nielsen LB 2006 Placental triglyceride accumulation in maternal type 1 diabetes is associated with increased lipase gene expression. Journal of Lipid Research 47 2581-2588.
Miyahara N, Miyahara S, Takeda K \& Gelfand EW 2006 Role of the LTB4/BLT1 pathway in allergen-induced airway hyperresponsiveness and inflammation. Allergology International 55 91-97.

Patsouris D, Mandard S, Voshol PJ, Escher P, Tan NS, Havekes LM, Koenig W, Marz W, Tafuri S, Wahli W et al. 2004 PPAR $\alpha$ governs glycerol metabolism. Journal of Clinical Investigation 114 94-103.

Peraza MA, Burdick AD, Marin HE, Gonzalez FJ \& Peters JM 2006 The toxicology of ligands for peroxisome proliferator-activated receptors (PPAR). Toxicological Sciences 90 269-295.

Portha B, Picon L \& Rosselin G 1979 Chemical diabetes in the adult rat as the spontaneous evolution of neonatal diabetes. Diabetologia 17 371-377.

Ramsay TG, Karousis J, White ME \& Wolverton CK 1991 Fatty acid metabolism by the porcine placenta. Journal of Animal Science 69 3645-3654.

Ringseis R, Gutgesell A, Dathe C, Brandsch C \& Eder K 2007 Feeding oxidized fat during pregnancy up-regulates expression of PPAR $\alpha$ responsive genes in the liver of rat fetuses. Lipids in Health and Disease 66.

Schaiff WT, Knapp FF Jr, Barak Y, Biron-Shental T, Nelson DM \& Sadovsky Y 2007 Ligand-activated peroxisome proliferator activated receptor gamma alters placental morphology and placental fatty acid uptake in mice. Endocrinology 148 3625-3634.

Schwartz R \& Teramo KA 2000 Effects of diabetic pregnancy on the fetus and newborn. Seminars in Perinatology 24 120-135.

Shekhawat P, Bennett MJ, Sadovsky Y, Nelson DM, Rakheja D \& Strauss AW 2003 Human placenta metabolizes fatty acids: implications for fetal fatty acid oxidation disorders and maternal liver diseases. American Journal of Physiology. Endocrinology and Metabolism 284 E1098-E1105.

Sinner D, Caviglia JM, Jawerbaum A, Igal RA \& Gonzalez E 2003 Lipid metabolism in the embryos of diabetic rats during early organogenesis: modulatory effect of prostaglandin E2. Reproduction, Fertility, and Development 15 75-80.

Soria A, Bocos C \& Herrera E 2002 Opposite metabolic response to fenofibrate treatment in pregnant and virgin rats. Journal of Lipid Research 43 74-81.

Wang Q, Fujii H \& Knipp GT 2002 Expression of PPAR and RXR isoforms in the developing rat and human term placentas. Placenta 23 661-671.

Watts GF \& Dimmitt SB 1999 Fibrates, dyslipoproteinaemia and cardiovascular disease. Current Opinion in Lipidology 10 561-574.

White V, Gonzalez E, Capobianco E, Pustovrh C, Sonez C, Romanini MC \& Jawerbaum A 2004 Modulatory effect of leptin on nitric oxide production and lipid metabolism in term placental tissues from control and streptozotocin-induced diabetic rats. Reproduction, Fertility, and Development 16 363-372.

White V, Gonzalez ET, Capobianco E, Pustovrh C, Martinez N, Higa R, Baier M \& Jawerbaum A 2006 Leptin modulates nitric oxide production and lipid metabolism in human placenta. Reproduction, Fertility, and Development 18 425-432.

Xu Y, Wang Q, Cook TJ \& Knipp GT 2007 Effect of placental fatty acid metabolism and regulation by peroxisome proliferator activated receptor on pregnancy and fetal outcomes. Journal of Pharmaceutical Sciences 96 2582-2606.

Yessoufou A, Hichami A, Besnard P, Moutairou K \& Khan NA 2006 Peroxisome proliferator-activated receptor alpha deficiency increases the risk of maternal abortion and neonatal mortality in murine pregnancy with or without diabetes mellitus: modulation of $\mathrm{T}$ cell differentiation. Endocrinology 147 4410-4418.

Young DA, King DS, Chen M, Norris B \& Nemeth PM 1988 A novel method for measurement of triglyceride lipase activity: suitable for microgram and nanogram quantities of tissue. Journal of Lipid Research 29 527-532.

Received 16 January 2008

First decision 13 February 2008

Revised manuscript received 3 April 2008

Accepted 15 April 2008 